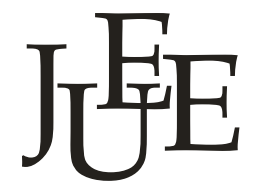

\title{
FLOOD RISK, COASTAL MEGACITIES, AND URBAN POOR: ASSESSING THE FUTURE URBAN FLOOD RISK IN THE H/E WARD OF MUMBAI
}

\author{
Pallavi Tyagi* \\ ${ }^{1}$ Department of Humanities and Social Sciences, Indian Institute of Technology, Bombay, India
}

Received 10 November 2019; received in revised form 02 May 2020; accepted 13 September 2020

\begin{abstract}
In India, Mumbai city is highly vulnerable to the threats posed by climate change, such as sea level rise, storm, and floods. The vulnerability of the city was demonstrated on the 26 July 2005 when thousands of houses were submerged in the water, and assets worth billions of rupees were damaged. The flood severely impacted the residents in informal settlements known as slums, which incurred substantial financial losses. With the increasing vulnerability of coastal megacities to urban floods, there is a need for an effective risk assessment \& Adaptation Planning. Hence this study aims to assess the current \& future Flood Risk faced by the H/E Ward (study area) of Mumbai. The flood risk assessment is performed using the standard catastrophe Risk modeling, which combines Hazard, exposure, and vulnerability. Various data sources such as Historical rainfall data, Elevation Data, Soil Database, Landsat Imagery, and census data were collected from multiple online sources to achieve this objective. The data processing is done using GIS, Hydrological \& Hydraulic Processes. As the H/E ward lies in the Mithi River catchment area, we processed the DEM and used the SCS-Curve Number and kinematic routing method to generate the peak discharge at the River Sub basins in HEC-HMS software. The River geometry is prepared in HEC-RAS software, and Flood Hazard Maps were prepared. The current \& future Risk analysis shows an increase in the inundation extent for the 100-year return period in the H/E Ward, which highlights that there would be an increase in the total affected Population and losses incurred by them. The study also highlights that the people's adaptive capacity is deficient. Most of the affected Population are poor people, employed in menial jobs, chosen to stay in the riskier site because of proximity to work. Hence this study highlights an urgent need for an effective Risk Management and Adaptation planning in the $\mathrm{H} / \mathrm{E}$ ward of Mumbai.
\end{abstract}

Keywords: Climate Change; Urban Flood Risk; Risk Assessment; Adaptation Planning.

(C) 2020 Journal of Urban and Environmental Engineering (JUEE). All rights reserved.

\footnotetext{
*Correspondence to: Pallavi Tyagi. E-mail: tyagipallavi093@gmail.com
} 


\section{INTRODUCTION}

The Fourth Assessment Report of the Intergovernmental Panel on Climate Change (IPCC) mentions how the coastal areas in both developing and industrialized economies face severe risks related to climate change (Bernstein, 2007). One of the severe risks faced by coastal Megacities is the increasing events of urban floods (Nicholls et al. 2008). A recent study of the 136 port cities showed that the population exposed to flooding is likely to increase from 40 million to 150 million by 2070 (Nicholls et al. 2008). The devastating flood in Bangkok in 2011, Manila in 2009 \& Mumbai in 2005 shows the vulnerability of these low lying areas to extreme weather events. The risk is especially high in developing and poor countries where a majority of the population in cities resides in slums, particularly at high risk from the impacts of climate and Natural Hazards. People residing in these areas are made even more vulnerable due to unsafe housing, lack of physical infrastructure and poor health (Baker, 2012).

With the increasing vulnerability of coastal megacities to urban floods, there is a need for an effective risk assessment \& Adaptation Planning. Hallegatte (2010) conducted a study in Mumbai to assess the current \& future flood risk and quantify the benefits of Adaptation options. For this, he followed the standard catastrophe Risk Modelling framework which involves the estimate of Hazard, Exposure and Vulnerability (Hallegatte, 2010).

The goal of flood hazard assessment is to understand the probability that a flood of a particular intensity will occur over an extended period of time (Wright, 2015). Hazard assessment aims to estimate this probability over periods of years to decades to support risk management activities. Another important component is the Exposure Mapping which aims to examine the economic assets and activities covered by the flood (Dhiman, 2019). Then the other major component of flood risk, aside from flood hazard, is flood vulnerability. The goal of vulnerability assessment is to find the impact of flood on the systems such as Physical Infrastructure and Businesses.

\section{An Overview of Study Area: Mumbai City}

Mumbai is one of the largest megacities in the world and ranked 4th after Tokyo, Mexico City, and New York City (Patankar, 2015). The population of the City has grown from 3 million in 1951 to 8 million in 1981 to 12.43 million in 2011 (MCGM, 2014 as cited in Patankar, 2015). The geographical location of the City and its physical, economic, and social characteristics make the City more vulnerable to the threats posed by climate change, such as sea-level rise, storm, and floods (Patankar, 2015).
The most vulnerable sections of the city are the residents in informal settlements known as slums, who comprise about $41 \%$ of the city's households (GoI, 2011). The vulnerability of the Mumbai city was shown on the $26^{\text {th }}$ July of 2005 when 447 people lost their lives and property worth billions of Rupees was destroyed. According to Hallegatte (2010), 174,885 houses were partially damaged and 2,000 fully damaged costing a total of 29,800 lakhs. Also, the trade \& commerce was extensively hit, with over 40,000 commercial establishments got damaged. Apart from economic losses, there were spread of waterborne disease which aggravated the impact of 2005 floods (Patankar, 2015).

\section{H/E Ward of Mumbai (Study Area)}

H/E Ward lies in the Western Suburbs of Mumbai. The boundary of the ward touches the bank of the Mithi River which then joins the Mahim creek. The land use pattern of the ward has significantly changed from 1980s after the reclamation projects carried out by the MMRDA. The population of the $\mathrm{H} / \mathrm{E}$ ward has increased by $28.5 \%$ within the years of 1991 to 2001 . This decadal change in the population shows an increased rate of urbanization in the area.

Figure 1 below shows the city Map of Mumbai city (left) and the H/E ward (Right). Thus, the objectives of the study: To assess the current and future Urban Flood Risk in the H/E ward of Mumbai: (a) To do the Hazard quantification modeling of $26^{\text {th }}-27^{\text {th }}$ July 2005 rainfall event and compare it against future frequencies of rainfall events based on historical data for the study area, (b) to do the exposure mapping of the affected population based on the Flood Plain Maps prepared in objective in the study area, (c) to do the exposure mapping of the economic losses incurred by the affected population based on the results of objectives in the study area, and (d) to study the Social Vulnerability of the affected population residing in the Study Area.

\section{THEORITICAL FRAMEWORK}

\section{Defining Urban Floods}

Flooding is one of the major disasters which disrupt the safety and amenities of the residents of Human Settlements (Jha et al., 2011). The Special Report on "Managing the Risks of Extreme Events and Disasters to Advance Climate Change Adaptation of the Intergovernmental Panel on Climate Change" (IPCC) has defined Flooding as: The overflowing of the normal confines of a stream or other body of water or the accumulation of river (fluvial) floods, flash floods, urban floods, pluvial floods, sewer floods, coastal floods, and glacial floods (Field et al., 2012, p. 559). 


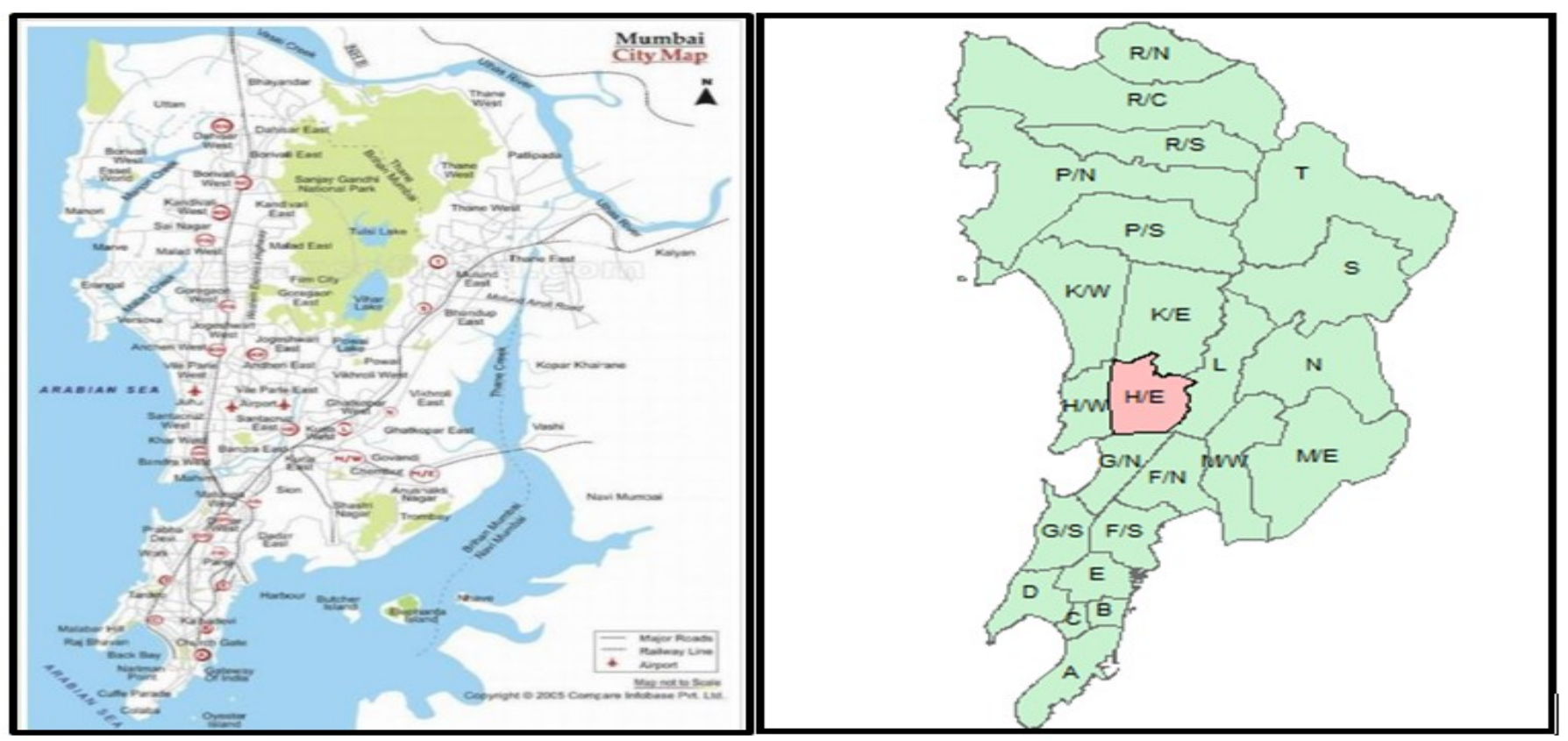

Fig. 1 City Map (Left) \& H/E Ward (Right). Source: MCGM website.

According to the National Disaster Management Guidelines (2008), the Mumbai Floods of 2005 has led to a change in understanding of Urban Floods. The report mentions that the causes of urban floods are different from Floods and hence the strategies to deal with the disaster should also be exclusive. Similarly, a World Bank Study states although it is hard to define Urban Flooding precisely but there is a need to understand why urban floods should be considered separately to Floods. The study mentions that the specificity of urban floods can be defined in terms of typology of settlement and appropriate measures at different city scales (Jha et al., 2011).

\section{Flood Risk Assessment and Management:}

Floods are frequently occurring destructive disasters. of risk is difficult and requires assessment of various parameters like size, topography, and land use, the types and characteristics of storms that produce rainfall and flooding in the region, and the number, location, and types of buildings and other assets that could be damaged. Poorly conducted risk assessment can cause poor risk management decisions which may lead to underestimation or overestimation of flood risk.

\section{Flood Hazard Assessment}

The goal of flood hazard assessment is to understand the probability that a flood of a particular intensity will occur over an extended period of time (Wright, 2015). Intensity usually refers to the combination of flood depth and horizontal flood extent; although other intensity measures such as flow velocity and flood duration can also be important depending on the situation (Wright, 2005). This relationship between the probability of a flood and its intensity gives rise to the concept of return period, represented by the symbol $\mathrm{T}$ and expressed in terms of years. A T-year flood is the flood intensity that has a probability of $1 / T$ of being exceeded in a given year. This probability is called the exceedance probability.

\section{Rainfall Runoff Modelling}

Wright (2015) states that there are two main types of rainfall-runoff models: Lumped \& Distributed. Devia, Ganasri \& Dwarakish, (2015) explains how the Lumped models treat the watershed as a single unit such as TR55 Model. Also, the author explains Distributed model to use spatially varying data for precipitation, infiltration etc. Examples are SWMM model. Wright (2015) states that some of the popular models, such as HEC-HMS, discretize the watershed into a number of sub watersheds, each of which is then represented using a lumped rainfall runoff model.

\section{Vulnerability \& Exposure Assessment}

The other major component of flood risk, aside from flood hazard, is flood vulnerability (Wright, 2015). The author mentions that the goal of vulnerability assessment is to find the impact of flood on the systems. The author explains that Vulnerability can be of two types: Physical Vulnerability which includes damages to Physical Infrastructure. On the other hand, Non Physical Vulnerability shows the Social Vulnerability which includes trauma from the Flood events, recovery from a death in the Family, Spread of a water Borne disease and decreased nutrition. Exposure analysis aims to 
examine the economic assets and activities covered by the flood. Exposure is a geospatial mapping of the types of assets of interest relative to the flood hazard (i.e. flood extent).

\section{Flood risk Assessment in the Mumbai City}

Dhiman (2019) mentions about the various studies conducted in the Mumbai City for an effective Risk Assessment. There are studies that have looked at the impact of LULC on the Hydrological processes. These LULC maps were prepared using the GIS and Remote sensing methods. Also these studies have identified the vulnerable zones to flooding. Also there were studies that have carried out the participatory spatial risks mapping in the Dharavi region which encouraged the community participation. The method in this study proved to be a very empowering tool for local communities in tackling flood issues. Another study performed by Zope et al., (2015) finds the spatial and temporal variation of LULC change for coastal urban catchment of Mithi River. The models HEC-HMS and HEC-RAS were integrated with HEC-GeoHMS and HEC-GeoRAS for the preparation of maps.

\section{Project Description}

In this study, we aim to assess the current and Future Flood Risk in Mumbai (specifically the H/E Ward of Mumbai). After the major event of Mumbai Floods 2005, Hallegatte et al. (2010) conducted a study to assess the future Flood Risk in Mumbai to support the effective Risk Management. For the Risk quantification, Hallegatte et al., (2010) has adopted the standard Catastrophe Risk Modeling which combines the estimates of Hazard, Exposure and Vulnerability. For this study, we have a adopted a similar methodology and which is given below:

\section{METHODOLOGY}

The H/E Ward (study area) of Mumbai comes within the Mithi River Catchment Area. Hence, we processed the DEM of the River Basin and performed the Hydrological modeling using HEC-HMS to get the peak discharge at the River Sub basins and Outlet. Then the River geometry is prepared in the HEC-RAS software and Flood Hazard Maps were prepared.

\section{Mithi River Catchment Area}

Mithi River watershed extends between latitudes $19^{\circ} 0^{\prime} 15^{\prime \prime} \mathrm{N}$ and $19^{\circ} 15^{\prime} 0^{\prime \prime} \mathrm{N}$ and longitudes $72^{\circ} 45^{\prime} 0^{\prime \prime} \mathrm{E}-$ $73^{\circ} 0^{\prime} 0$ ' 'E. Mithi River originates at Powai and carries discharges from Powai and Vihar Lake and meets the Arabian Sea at Mahim Creek. It travels a total length of $17.3 \mathrm{~km}$ and has a catchment area of 7295ha. The river flows through the residential and industrial complexes of Saki Naka, Powai, and Kurla and passes through thickly populated areas like Jarimari, BKC, Dharavi and ends at Mahim creek. The river bed is very narrow at the initial stretch and broad at the BKC area.

Mithi River is considered an open-drain by nearby households that let out their raw sewage. The industrial/commercial establishment also let out their industrial waste, garbage, which remains highly unchecked. The severe degradation of the Mithi River has also become a threat to marine biodiversity. Both the banks of the River are highly encroached by small scale industries and godowns. Figure 2 shows the extent of the Mithi River (left) and the catchment area prepared using the HEC HMS 4.2.1 (Right).

\section{Data Sources}

a- For the research work, a 1- Arc-Second Global SRTM (Shuttle Radar Topography Mission) DEM for the study area is obtained from https://earthexplorer.usgs.gov/.

b- To detect the changes in the Land use patterns of the study area, Landsat TM image for the year 2005 have been obtained from https://earthexplorer.usgs.gov/.

c- For the soil data of the study area, The Harmonized World Soil Database which is a 30 -arc-second raster Database is obtained from the http://www.fao.org/soils-portal/soilsurvey/soil-maps-and-databases/harmonizedworld-soil-database-v12/en/.

d- The daily rainfall data from 1949 to 2005 for Santacruz station were obtained from the website https://power.larc.nasa.gov?dataaccess-viewer/.

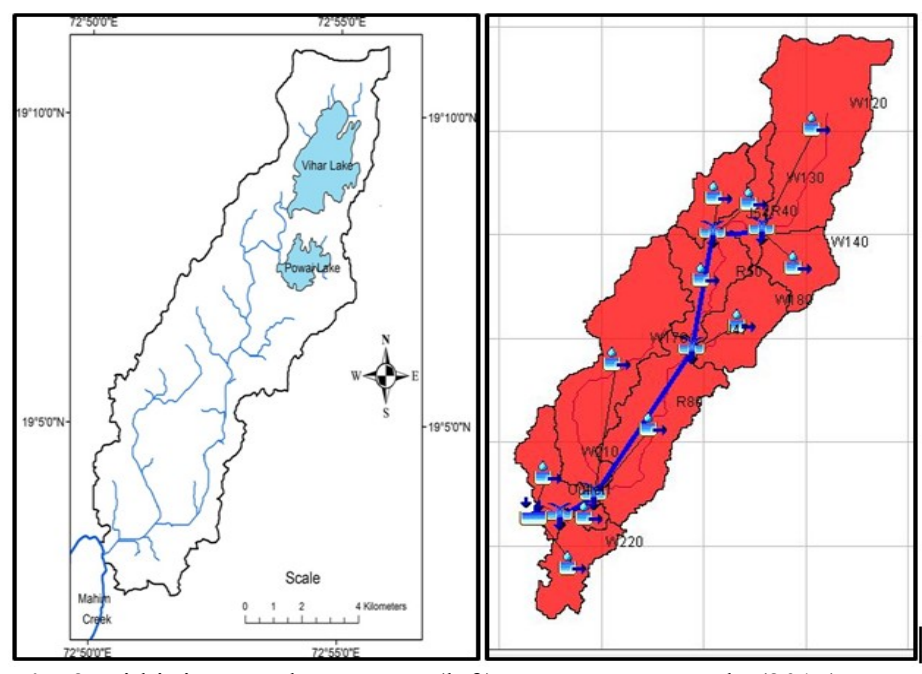

Fig. 2 Mithi river catchment area (left) Source: Zope et al., (2015) \& Catchment area prepared in HEC-HMS 4.2.1(Right) 
Data Preparation: Base Map Preparation for HECHMS using HEC-GeoHMS. The rainfall runoff modeling was carried out with the help of HEC-HMS 4. 2.1 and HEC-GeoHMS. An overview of the processing has been shown through the flow chart (Fig. 3) given below. The Methodology for generating the Rainfall Runoff modeling, the following steps has been followed: Firstly the input Terrain Data DEM is refined using the DEM Reconditioning. Then the preprocessing is done using HEC-GeoHMS. Fill sinks is required to fill the existing Depressions present in the RAW DEM which prevent the water from stagnating during flow computation. The flow direction layer was derived from depression less DEM. Figure 4 below gives the RAW DEM for the Mithi River Catchment Area. The hydrologic parameters for each sub basin are calculated using the union of Soil and Land Use Data. Table 1 shows the selected processes for Hydrologic modelling below.

For the Curve Number Grid generation, Landsat satellite images of year 2005 are used. Landuse classification is done using supervised maximum likelihood classification in ArcGIS 10.3. Figure 5 below shows the Landuse map of H/E Ward for the year 2005. Harmonized World Soil Database is used for obtaining soil map of Mithi River Basin. For the Curve Number generation, the landuse map and Soil Map are coupled and hydrologic Soil group is assigned.

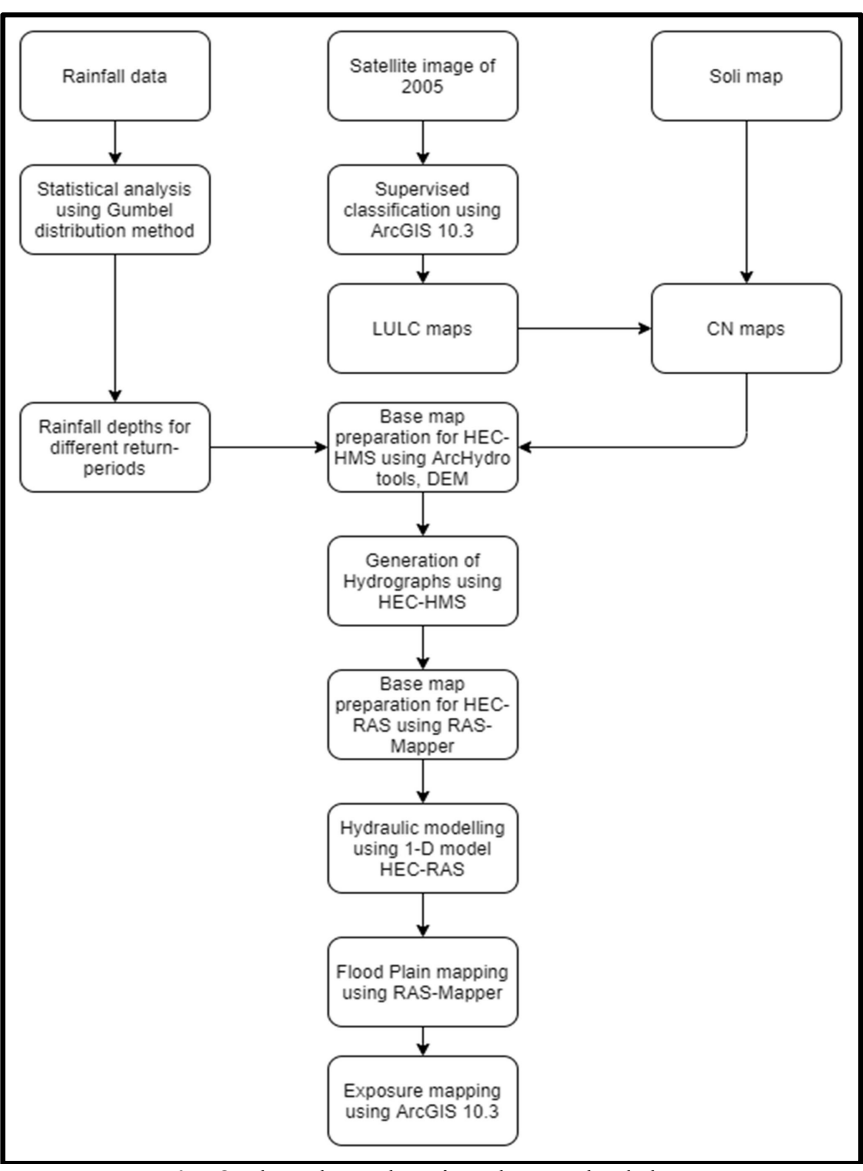

Fig. 3 Flowchart showing the Methodology
Table 2 gives the Curve Number look up table for the year 2005. The CN look table is borrowed from the sources who have conducted the study for the Mithi river catchment area. Also, the LULC map was reclassified for the category of Mangrove \& Dense Vegetation. After this, model files such as backgroundmap file, basin model file and meteorological model file required for HEC-HMS were generated. Specified Hyetograph method was chosen for creating meteorological model file for both basins. After completion of building model framework in HECGeoHMS, modeling was performed in HEC-HMS by importing files from ArcGIS. A 24h storm rainfall depth having 2-, 10-, 50-, and 100- years return period were given as input to the hydrological model in the HECHMS model. The detail description is added in the Hazard Quantification section.

Table 1. HMS process

\begin{tabular}{cl}
\hline HMS Processes & \multicolumn{1}{c}{ Method } \\
\hline LOSS & SCS Unit Hydrograph \\
TRANFORM & SCS Unit Hydrograph \\
BASE FLOW & None \\
ROUTING & Kinematic Wave Method \\
\hline
\end{tabular}

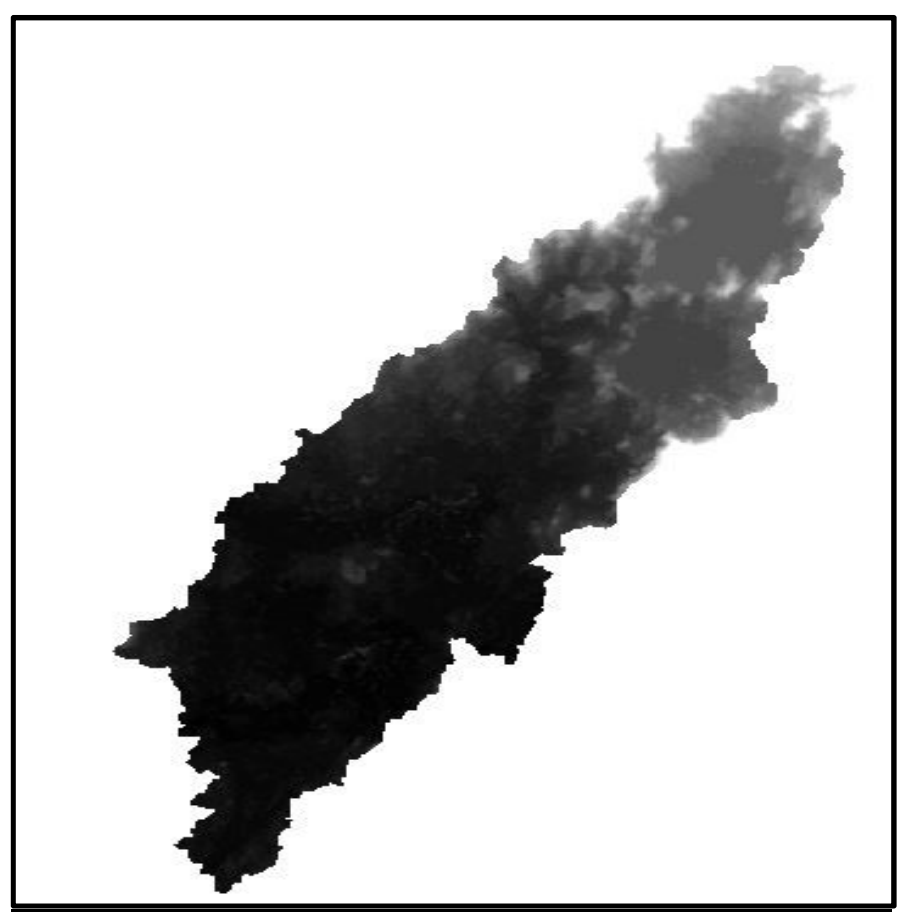

Fig. 4 DEM for the Mithi River Catchment area

Table 2. CN look-up Table

\begin{tabular}{lrrrr}
\hline Landuse & A & B & C & D \\
\hline Open land & 49 & 69 & 76 & 84 \\
Built-up & 69 & 76 & 84 & 92 \\
Water body & 100 & 100 & 100 & 100 \\
Vegetation & 30 & 70 & 79 & 82 \\
Dense vegetation and mangrove & 25 & 65 & 75 & 83 \\
\hline
\end{tabular}




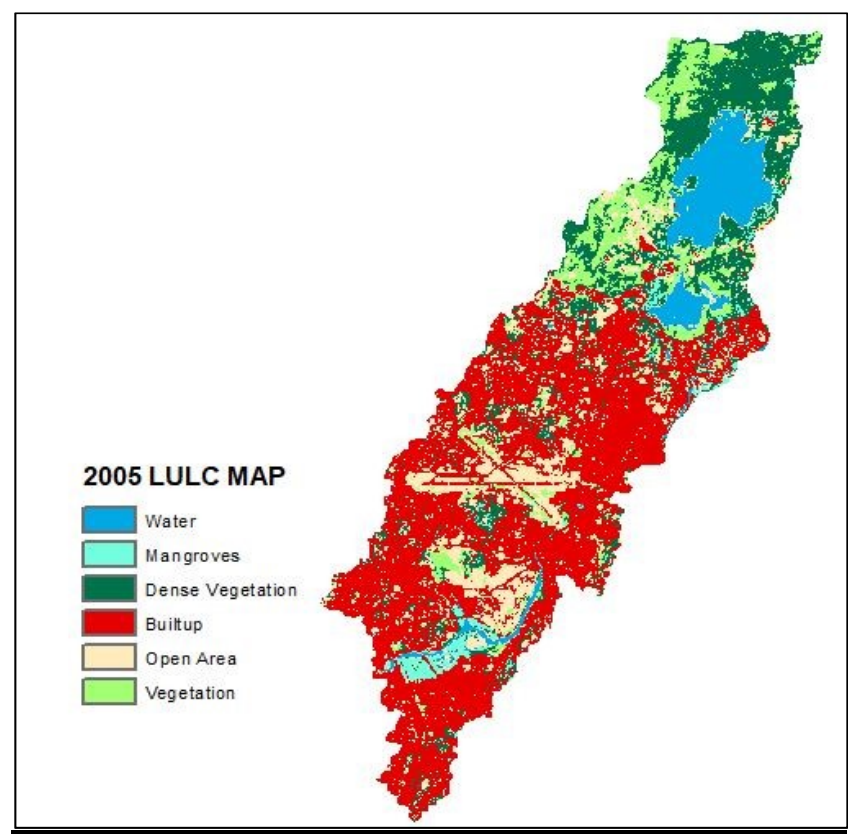

Fig. 5 LULC Map for the year 2005 for Mithi River Basin

\section{Hydraulic Model Development}

For the research work, we used HEC-RAS version 5.0.7. We focus on one-dimensional, steady flow simulations. HEC-RAS computes water elevations at various locations along the channels. The data needed to perform this computation is geometry data and steady flow data. The research work is not intended for calibrating or validating the Mithi-River basin HECRAS model. This work tries to find out water surface profile relationship with Rainfall intensity having a base land use map. This paper used RAS-Mapper which is an integrated module of HEC-RAS for creating the geometric profile. The geometric file includes information about river centerlines, banklines, flowpath lines, cross-section and other physical attributes of river channel. The dataset used for RAS-Mapper was the DEM and the river network for the Mithi River catchment River network profile was extracted from stream in ArcGIS. The terrain file doesn't have a clearly demarcated river network. So, we overlaid the stream on top of the terrain file to get the river network which is shown below in (Fig. 6).

We got 11 reaches from ArcGIS. We only used 5 reaches. Other reaches were very small compared to above 5 reaches and hence were ignored. Cross-section contains information about elevation of the main channel and over banks, bank stations (locations which separates main channel from the flood plain) and downstream reach lengths (distance between adjacent cross-sections). We placed 70 cross sections across the main channel with spacing ranging from $70 \mathrm{~m}$ to $950 \mathrm{~m}$ between cross-sections. The cross-sectional view is shown in (Fig. 7).

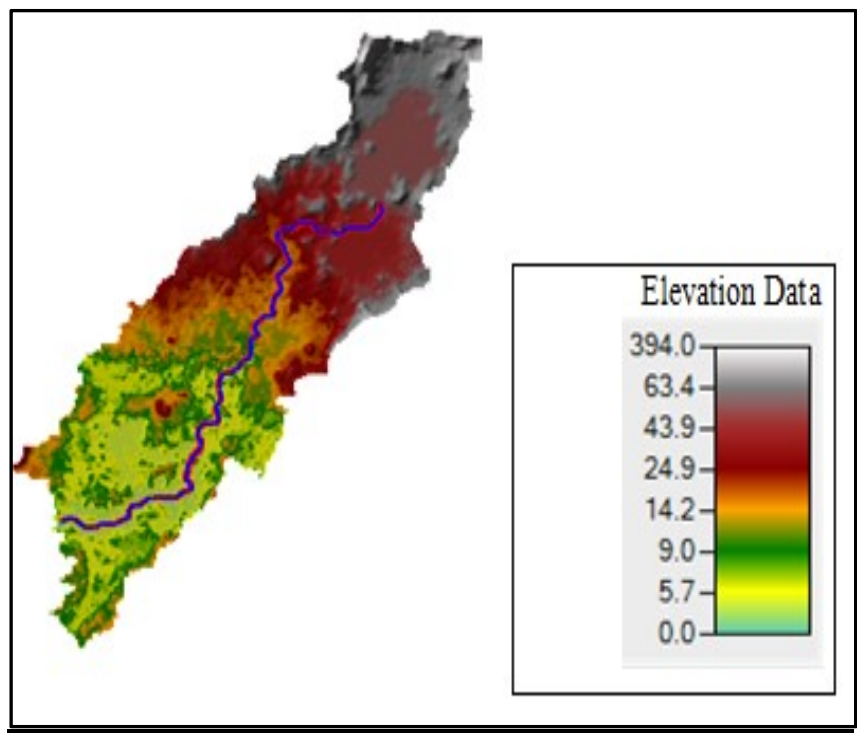

Fig. 6 Mithi River Network

The manning's roughness coefficient for the LULC classes of Built Up, Land, Water Body, Vegetation and Forest and open Land are 0.0015, 0.03, 0.10 and 0.15 respectively (Zope et al., 2015). Steady flow data comprises of initial conditions and boundary conditions. Boundary conditions must be specified for each modelled constituent at all locations where flow enters the system. We use the normal depth as the downstream boundary condition in the mithi-river basin HEC-RAS model. Because the energy slope is unknown, we approximated it by using the slope of the channel bottom which is 0.002 . Initial conditions is established by entering the flow data for each reach and have the program perform a steady flow backwater run to compute the corresponding stages at each cross section. We got the peak discharges for each reach from HECHMS. We took a single reach and we entered the peakdischarge for cross-sections corresponding to that reach.

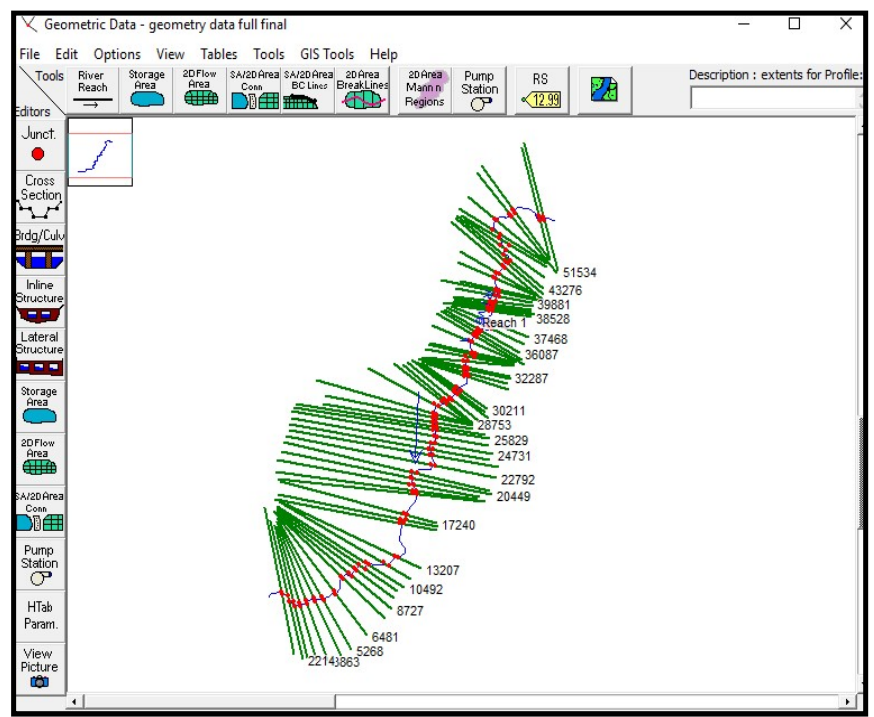

Fig. 7 Cross sectional View for Mithi River Basin 


\section{Run}

We simulated the HEC-RAS model for subcritical flow regime.

\section{RESULTS AND ANALYSIS}

\section{Hazard Quantification}

For the first objective, we modeled the extreme rainfall event occurred in the Mumbai City in the year 2005. The hourly rainfall data for the time period of $26^{\text {th }}$ July 12:00 PM to $27^{\text {th }}$ July of the Vihar Station was considered. This was given as input to the hydrological model in the HEC-HMS model. (The detailed description about the model $\&$ is given in the methodology section). As a result, the flood hydrograph and peak discharge were determined at the outlet, sub basins and reaches. The geometry of the Mithi river basin was created in HEC-RAS using RAS-Mapper. The flow of water was assumed to be steady. The manning's coefficient for the river bed was 0.018 . Peakdischarge given by HEC-HMS, river geometry and manning's coefficient were given as input to the HECRAS model.

Figure 8 shows the Flood depth and flood inundation maps obtained from HEC-RAS for the Mithi River Catchment Area modeled for the Flood event of $26^{\text {th }}$ and $27^{\text {th }}$ July 2005. Also, the Table 3 below shows the comparison of the modelled Flood Footprint prepared by the researcher in HEC-RAS software to the observed flood extent prepared in SWMM model by Hallegatte et al., 2010. This flood extent map is prepared for the Mithi River Catchment Area.

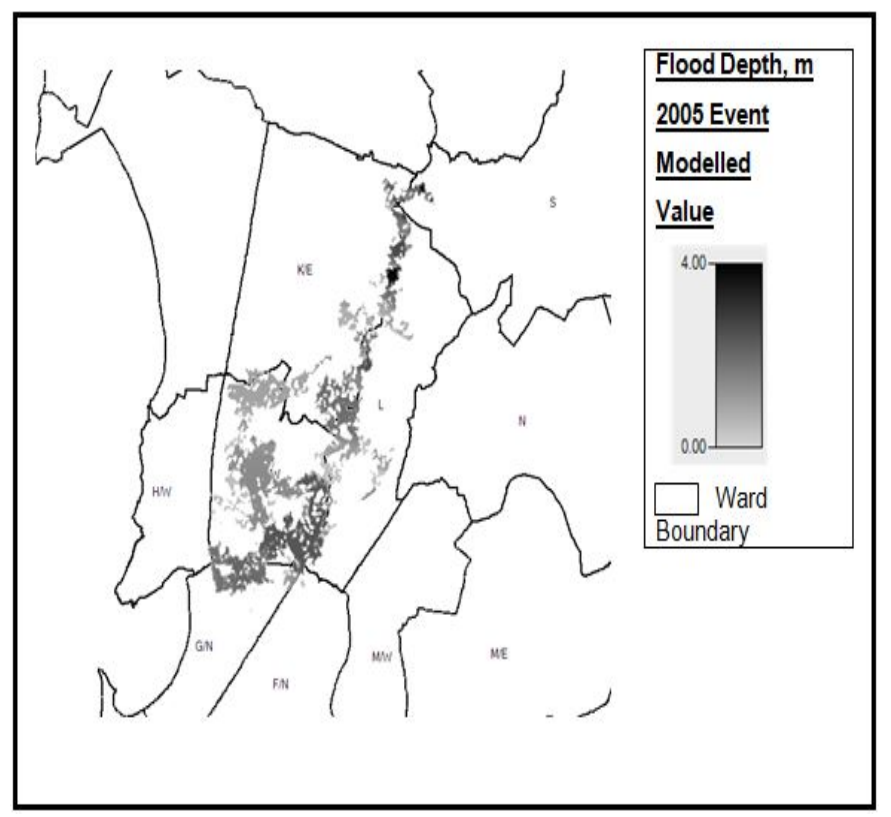

Fig. 8 Flood Plain Map including Water Depth and Inundation extent for Mithi River Basin
Table 3. Comparison of observed flood extent vs. modelled flood extent using HEC RAS

\begin{tabular}{lc}
\hline Observed Flood Footprint 2005 floods & $20\left(\mathrm{~km}^{2}\right)$ \\
SWMM Model Flood Footprint (Hallegatte et & $16\left(\mathrm{~km}^{2}\right)$ \\
al., 2010) & $11.09\left(\mathrm{~km}^{2}\right)$ \\
HEC RAS Modelled Footprint in our & \\
Research Paper & \\
\hline
\end{tabular}

\section{Limitations}

There is mismatch in the observed and modeled flood extent. Some of the limitations of the modeling were as follows: (1) hourly data for the Santacruz station could not be obtained as it stopped working due to the major flood event; (2) low resolution of DEM is used to prepare the river geometry. Hence this can also lead to mismatch in the results.

\section{Flood Plain Maps for various return periods}

To prepare the Flood Plain Maps for different return periods, the daily rainfall data from 1949 to 2005 for Santacruz station was used. The rainfall frequency analysis of maximum rainfall depth for daily rainfall data for each year was carried out. The frequency analysis of different return periods was done by extreme value Gumbel type-1 distribution (Zope, Eldho, \& Jothiprakash, 2012). For the IDF Curve generation, Kothyari \& Garde (1992) gives an equation that can be used to derive IDF curves for shorter durations and different return-periods.

$I_{t}^{T}=C \frac{T^{0.20}}{t^{0.71}}\left(R_{24}^{2}\right)^{0.33}$

where $\mathrm{T}$ (in years) is the return period, $\mathrm{t}$ (in hours) is the duration $=8.3$ is a constant(for western region) and $\mathrm{I}_{\mathrm{t}}^{\mathrm{T}}$ is Intensity(in $\mathrm{mm} / \mathrm{hr}$ ) for return-period $\mathrm{T}$ and duration $\mathrm{t}$. $\mathrm{R}^{2}{ }_{24}$ is the amount of rainfall(in $\mathrm{mm}$ ) for 24-hours and 2 year return-period. $I_{t}^{T}$ for $t=1$ hour is 117.16 and 101.99 for $T=100$ and $T=50$, respectively (Kothyari \& Garde, 1992).

The 1-hour rainfall intensity including the 2005 rainfall event for 100-year return period were found as $117.11 \mathrm{~mm}$. Figure 9 below shows the IDF curve for 1 hour duration. A $24 \mathrm{~h}$ storm rainfall depth having 2-, 10-, 50 -, and 100- years return period were given as input to the hydrological model in the HEC-HMS model. (The detailed description about the model $\&$ is given in the methodology section). As a result, the flood hydrograph and peak discharge were determined at the outlet, sub basins and reaches. The flood plain map including the flood water depth and flood inundation extent was prepared for the various return periods of 5-, 10-, 50-, and 100 years is shown in the Fig. 10 and Fig. 11 below for the Mithi River Catchment Area. 


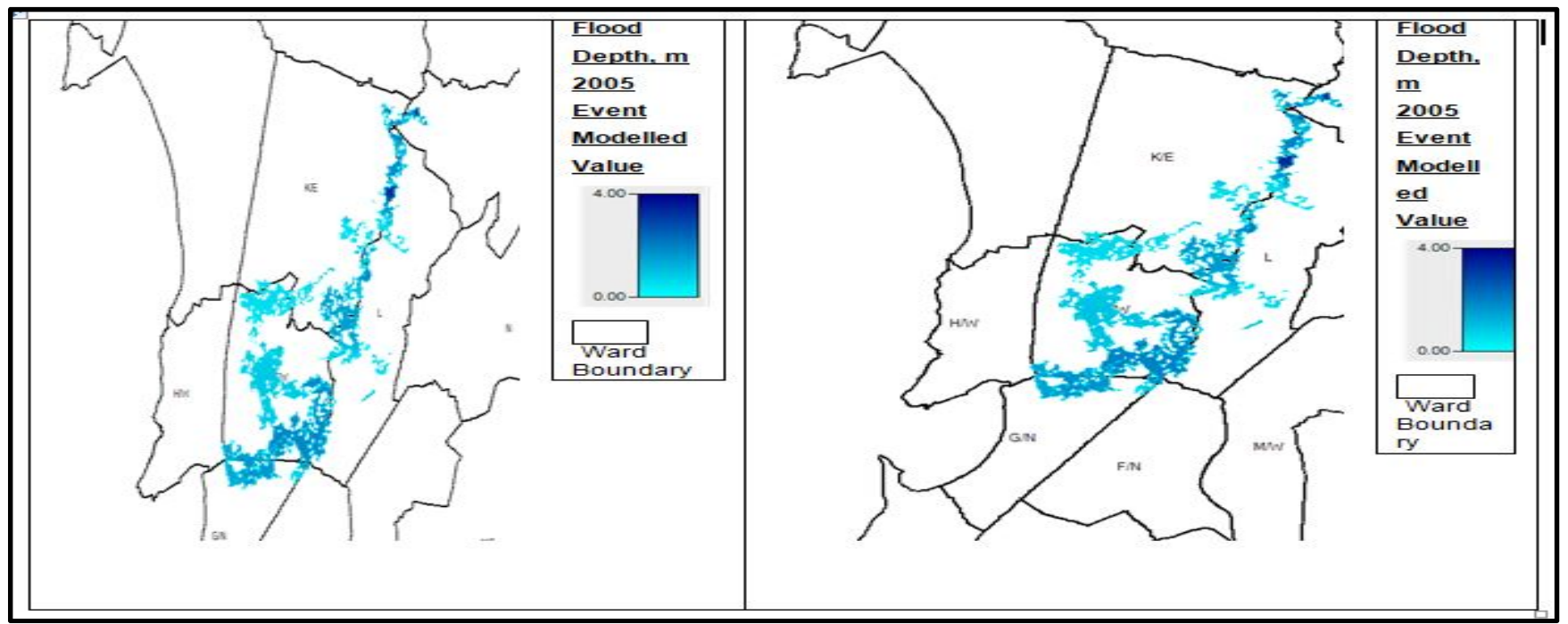

Fig. 10 left- Flood Extent Map for 5 year Return Period and Right - Flood Plain Map for 10 year Return Period

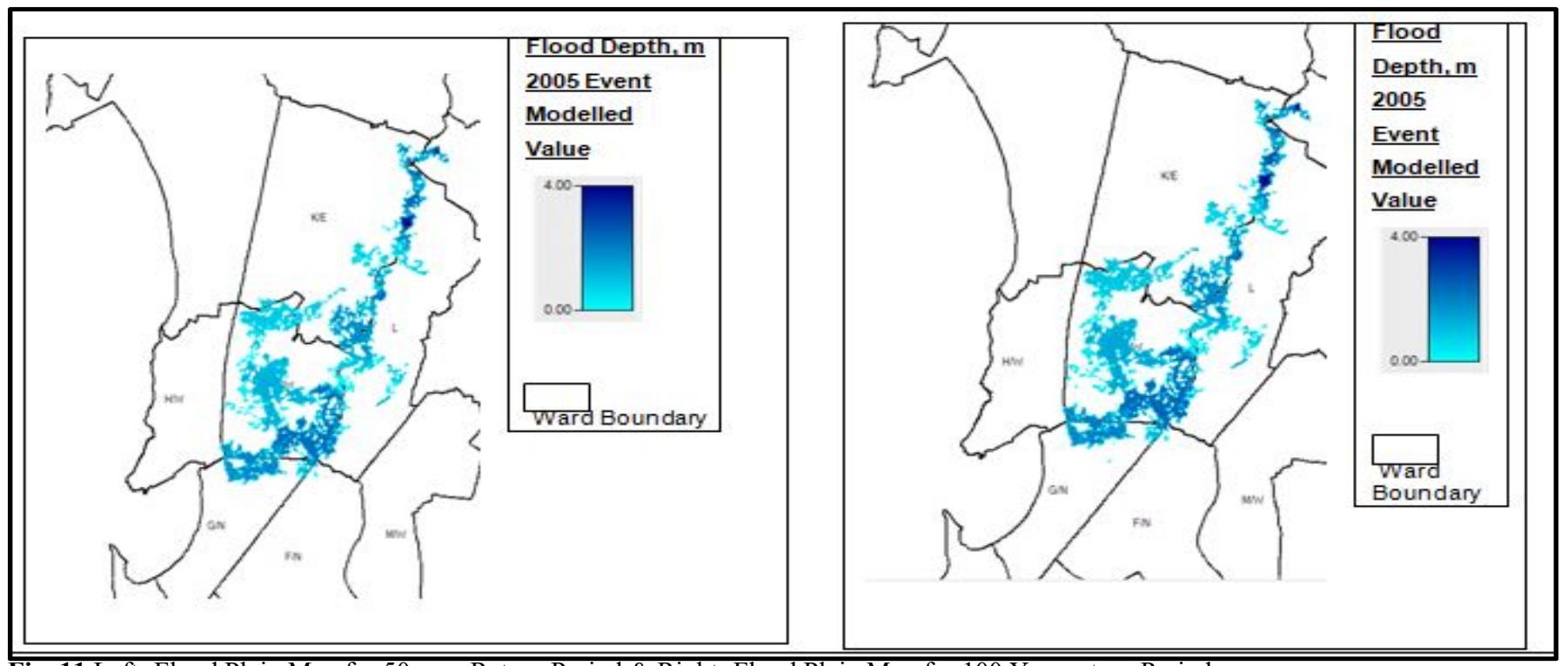

Fig. 11 Left- Flood Plain Map for 50 year Return Period \& Right- Flood Plain Map for 100 Year return Period

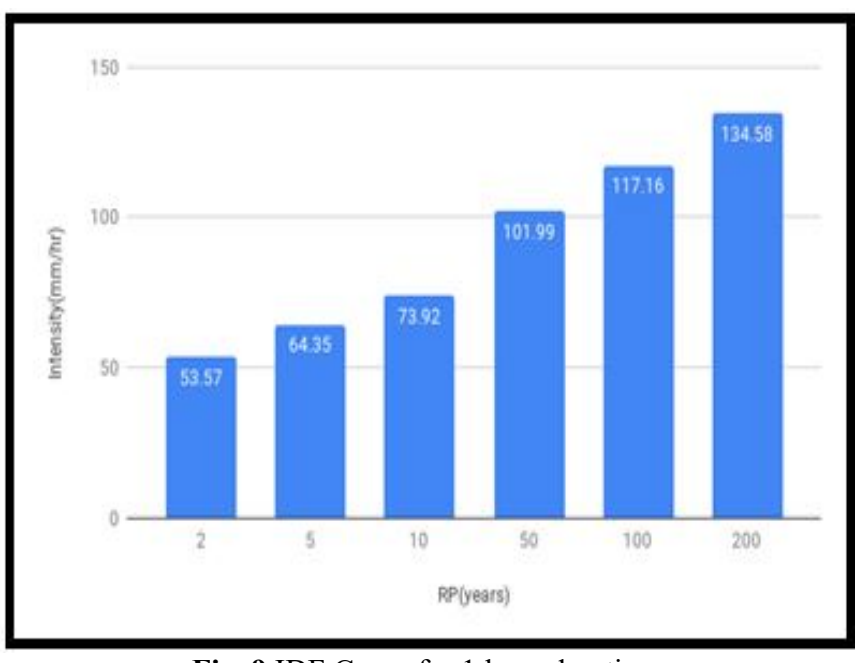

Fig. 9 IDF Curve for 1 hour duration.

One of the potential limitations of the flood modeling technique is low resolution of the DEM which can generate skew in the findings. Due to the extreme event of 2005 floods, where $944 \mathrm{~mm}$ of rainfall was measured at the Santacruz Station. Hence including such an outlier based on a short 40-year rainfall time series might skew the findings (Hallegatte, 2010). 3Simulating a short 30 -year rainfall time series data and extending it for 100 years might bring inadequacies in the findings.

\section{Flood Plain and Flood Inundation Extent for $\mathbf{H} / \mathbf{E}$ Ward of Mumbai}

\section{Flood Plain Map for the H/E Ward}

Table 4 below shows the flood extent for 5-, 10-, 50-, 100 return period for the Mithi River Catchment Area. In the above section, we created the Flood inundation map for Mithi River Basin, for the detailed analysis of the H/E Ward, we have extracted the H/E ward from the Mithi River Basin and 
Table 4. Flood Inundation Extent for Mithi Basin Catchment Area modelled in HEC-RAS

\begin{tabular}{lc}
\hline \multicolumn{1}{c}{ Simulated Event ID } & Flood extent in $\mathrm{km}^{2}$ \\
\hline 2005 Event & 11.09 \\
5-year Return Period & 8.30 \\
10-year Return Period & 8.74 \\
50-year Return Period & 9.82 \\
100-year Return Period & 10.24 \\
\hline
\end{tabular}

found the water depth \& inundation extent. Figure 12 below shows the Flood Plain Map including Water Depth and inundation extent for H/E Ward. In the same way, the Fig. 13 and Fig. 14 show the Flood Plain Map including Water Depth and Inundation Extent in the $\mathrm{H} / \mathrm{E}$ Ward of Mumbai for the return period of 5-, 10-, 50- and 100 years. Table 5 below shows the Flood extent in the H/E Ward for the return period of 5-, 10-, 50-, and 100- modeled in the HEC-RAS software.

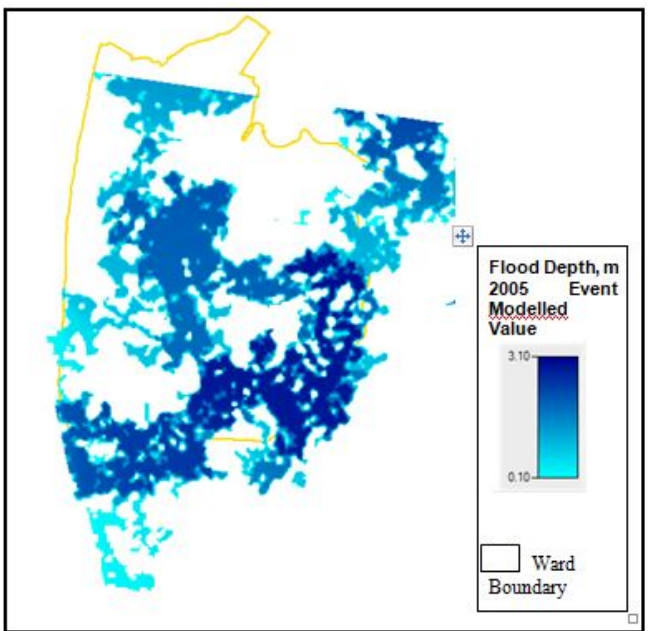

Fig. 12 Flood Plain Map including Water Depth and inundation extent for $\mathrm{H} / \mathrm{E}$ Ward

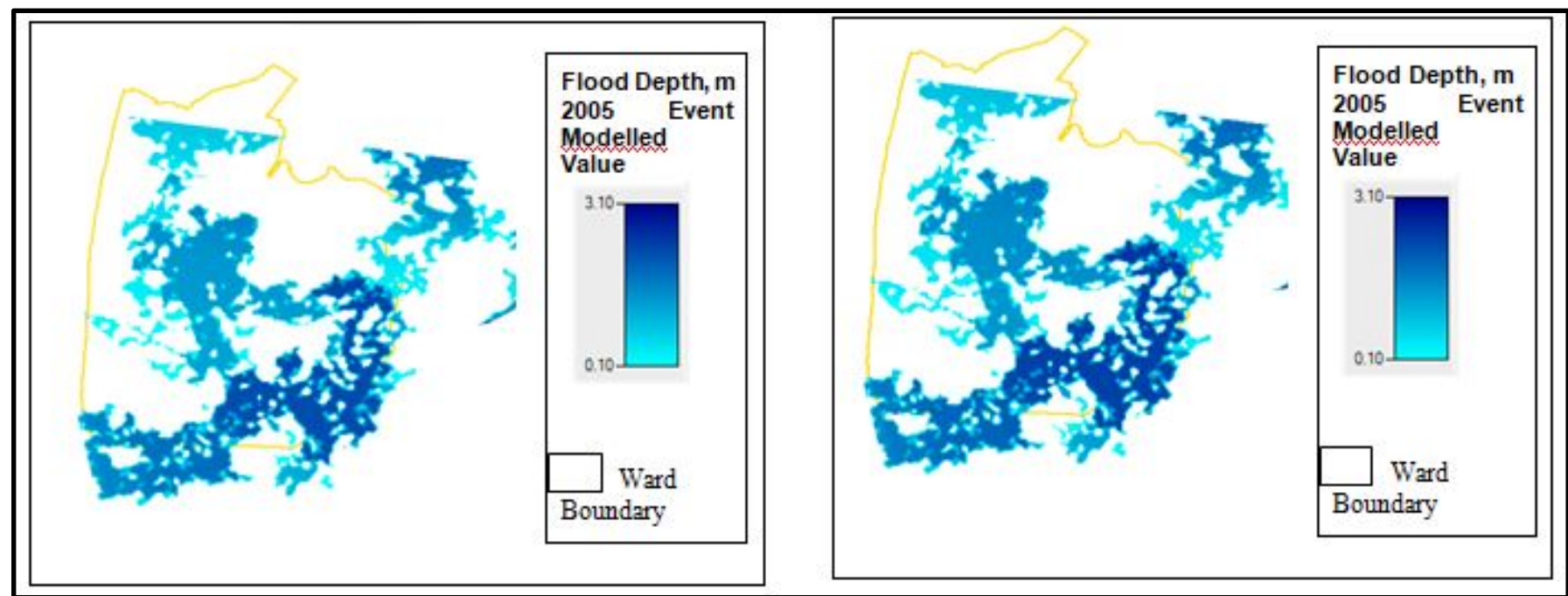

Fig. 13 Left: Flood Plain Map including for 5 year return Period for H/E Ward \& Right: Flood Plain Map including for 10 year return Period for $\mathrm{H} / \mathrm{E}$ Ward

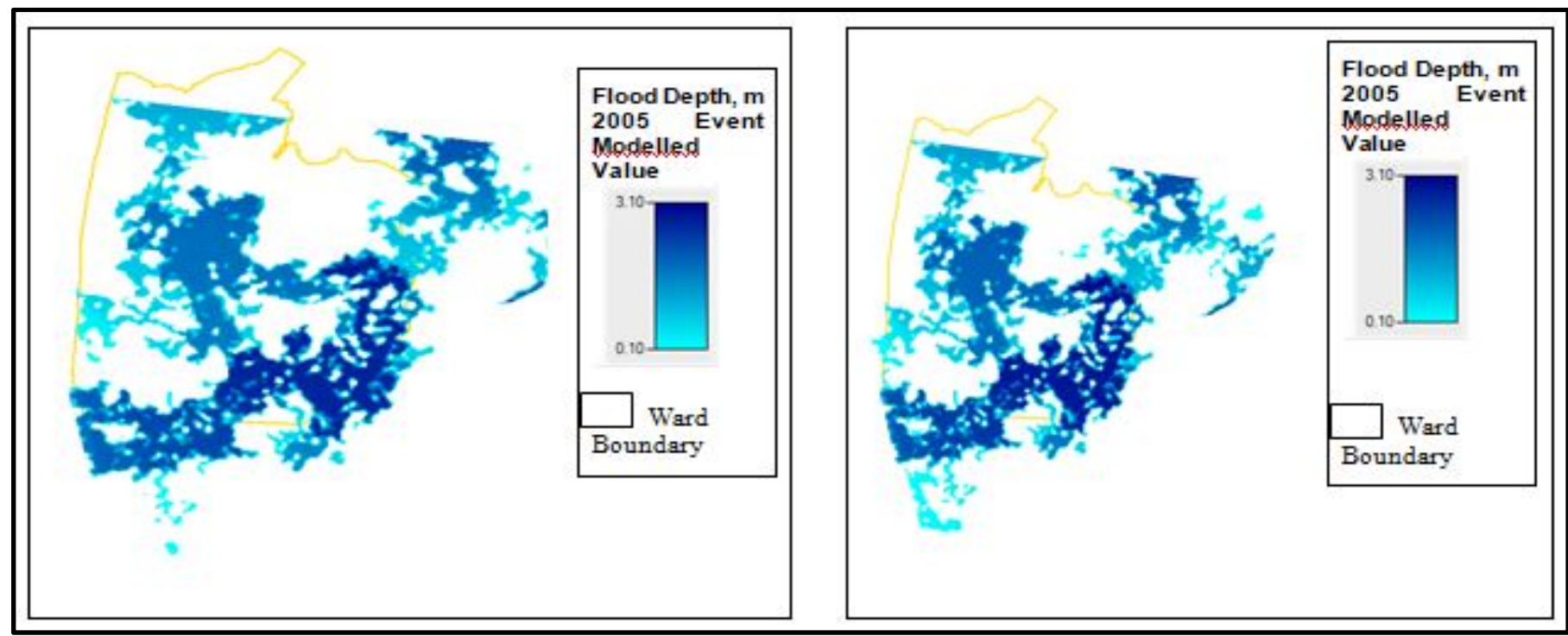

Fig. 14 Left: Flood Plain Map including for 50 year return Period for H/E Ward \& Right: Flood Plain Map including for 100 year return Period for H/E Ward 
Table 5. Flood Extent for $\mathrm{H} / \mathrm{E}$ Ward of Mumbai (Study Area) modelled in HEC-RAS

\begin{tabular}{ll}
\hline Simulated Extent ID & Flood extent in $\mathrm{km}^{2}$ \\
\hline 2005 flood event & 9.40 \\
5-year Return Period & 7.58 \\
10-year Return Period & 7.88 \\
50-year Return Period & 8.72 \\
100-year Return Period & 9.44 \\
\hline
\end{tabular}

\section{Exposure Mapping}

\section{Affected Population in the H/E Ward}

The exposure Map shows the spatial distribution of all the people and properties in the study area (Hallegatte, 2010). For our study, we will be focusing on the affected population. The exposure data can then be combined with the flood footprint to estimate the affected exposure (Hallegatte, 2010). For our study, we have assumed an unchanged city, where the population and growth factors would be helpful to estimate the future exposure. A digitalized population map is prepared from the census data, 2011 (Government of India, 2011). The population data was distributed evenly over a $100 \mathrm{~m}$ Grid. As in the above section, we have prepared the Flood Plain map for the H/E ward. The exposure Map and the inundation Map were spatially joined to calculate the affected Population. According to the 2011 census, the total population of $\mathrm{H} / \mathrm{E}$ ward is 5, 56,891 . This population data was spatially distributed over the $100 \mathrm{~m}$ grid and a density of 43,025 was found. Table 7 shows the affected population for 5-, 10-, 50-, 100 return periods for the H/E ward of Mumbai.

To compare it with the observed affected population in the $\mathrm{H} / \mathrm{E}$ ward, a World Bank study is referred which has conducted detailed surveys in the 6 most affected wards of Mumbai (Patankar, 2015). The study shows that $33 \%$ of the affected population lives in the Slum area and $48 \%$ of the affected population lives in apartments. The report mentions that majority of the population residing in the slums are BPL (Below poverty Line) families and have very poor capacity to deal with the disasters.

\section{Economic losses Incurred by the People in $\mathbf{H} / \mathbf{E}$ Ward}

For this section, we have referred to a World Bank Study which was conducted in the 6 most affected wards of Mumbai (Patankar, 2015). They have performed a detailed survey regarding the direct losses incurred by the people in the affected wards. Figure $\mathbf{1 5}$ below gives the average household losses incurred due to the following reasons as shown in different categories.
Table 6. Impacts on Households during the 2005 Extreme event

\begin{tabular}{|c|c|c|c|c|c|c|}
\hline & K East & H East & F North & F South & L Ward & P North \\
\hline & \multicolumn{6}{|c|}{ (Figures in bracket as \% of average household monthly income) } \\
\hline Income loss due to floods & 10474 & 8543 & 5164 & 8323 & 22578 & 14894 \\
\hline & (69.8) & (57.0) & (25.8) & (41.6) & (112.9) & (74.5) \\
\hline $\begin{array}{l}\text { Amount spent on } \\
\text { repair/rebuilding of } \\
\text { house/premises }\end{array}$ & $\begin{array}{r}22270 \\
(148.5)\end{array}$ & $\begin{array}{c}26191 \\
(174.6)\end{array}$ & $\begin{array}{c}34335 \\
(171.7)\end{array}$ & $\begin{array}{r}42967 \\
(214.8)\end{array}$ & $\begin{array}{r}22457 \\
(112.3)\end{array}$ & $\begin{array}{c}27118 \\
(135.6)\end{array}$ \\
\hline $\begin{array}{l}\text { Losses due to damage to } \\
\text { household appliances } \\
\text { (TV, refrigerator, washing } \\
\text { machine, etc.) }\end{array}$ & $\begin{array}{l}13190 \\
(87.9)\end{array}$ & $\begin{array}{r}15469 \\
(103.1)\end{array}$ & $\begin{array}{l}13442 \\
(67.2)\end{array}$ & $\begin{array}{l}10081 \\
(50.4)\end{array}$ & $\begin{array}{l}11325 \\
(56.6)\end{array}$ & $\begin{array}{r}23923 \\
(119.6)\end{array}$ \\
\hline $\begin{array}{l}\text { Losses on account of damage } \\
\text { to household assets (Furniture } \\
\text { and utensils) }\end{array}$ & $\begin{array}{c}9735 \\
(64.9)\end{array}$ & $\begin{array}{l}11061 \\
(73.7)\end{array}$ & $\begin{array}{l}11756 \\
(58.8)\end{array}$ & $\begin{array}{r}6602 \\
(33.0)\end{array}$ & $\begin{array}{r}7121 \\
(35.6)\end{array}$ & $\begin{array}{l}10417 \\
(52.1)\end{array}$ \\
\hline $\begin{array}{l}\text { Losses due to damages to } \\
\text { vehicles } \\
\text { (Car, Motorcycle, Bicycle) }\end{array}$ & $\begin{array}{l}12974 \\
(86.5)\end{array}$ & $\begin{array}{r}9153 \\
(61.0)\end{array}$ & $\begin{array}{l}11833 \\
(59.2)\end{array}$ & $\begin{array}{l}1250 \\
(6.3)\end{array}$ & $\begin{array}{r}5478 \\
(27.4)\end{array}$ & $\begin{array}{r}7232 \\
(36.2)\end{array}$ \\
\hline
\end{tabular}

Table 7. Affected Populations for different return period in the H/E Ward of Mumbai

\begin{tabular}{ll}
\hline Simulated Extent ID & Affected Population \\
\hline 2005 Flood event & 358,828 \\
5-year Return Period & 299,023 \\
10-year Return Period & 308,489 \\
50-year Return Period & 354,526 \\
100-year Return Period & 360,549 \\
\hline
\end{tabular}

According to the World Bank study, the average household Size is 5 (members in the Family) (Patankar, 2015). Hence we divided the affected population (Previous section) by the average household size number and get the number of households affected during the floods. Then we multiply the losses with the affected number of households to get the total losses under the different categories. Table 8 shows the losses incurred by the affected Population in the $\mathrm{H} / \mathrm{E}$ ward of Mumbai.

\section{Effect on Marginalized Population}

In the field of Disaster risk reduction, traditionally, there has been a focus on engineered infrastructure and technology-related measures. However, several studies have emphasized the need to improve the resilience of people to cope with Disasters (Brocal, 2019). Communities who have faced frequent disasters have developed different ways to deal with the situation (Parthasarthy, 2009). This shows how the flood risk can be mitigated with increased involvement of people in the Disaster reduction cycle. In this Section, we would look at the social vulnerability of the people residing in the $\mathrm{H} / \mathrm{E}$ ward.

\section{Analyses of the Demographic data for the H/E Ward}

The social vulnerability of a community depends on various factors such as Literacy level, Physical infrastructure i.e. Road network, Health Facilities, Work profile of the population etc (Gonzalez et al., 2019). To understand the social vulnerability of the H/E Ward, the data from the following sources have been analyzedcensus data for the year 2001 and 2011, Human Development report of Mumbai 2009. 
Table 8. Economic losses incurred by the affected population in the H/E Ward of Mumbai

\begin{tabular}{|c|c|c|c|c|c|c|}
\hline Year & $\begin{array}{l}\text { Affected } \\
\text { households }\end{array}$ & $\begin{array}{l}\text { Income } \\
\text { loss due to } \\
\text { floods }\end{array}$ & $\begin{array}{l}\text { Amount spent on } \\
\text { repair/rebuilding } \\
\text { of } \\
\text { house/premises }\end{array}$ & $\begin{array}{l}\text { Losses due } \\
\text { to damage to } \\
\text { household } \\
\text { appliances } \\
\text { (TV, } \\
\text { refrigerator, } \\
\text { washing } \\
\text { machine, } \\
\text { etc.) }\end{array}$ & $\begin{array}{l}\text { Losses on } \\
\text { account of } \\
\text { damage to } \\
\text { household } \\
\text { assets } \\
\text { (Furniture } \\
\text { and } \\
\text { utensils) }\end{array}$ & $\begin{array}{l}\text { Losses due } \\
\text { to damages } \\
\text { to vehicles } \\
\text { (Car, } \\
\text { Motorcycle, } \\
\text { Bicycle) }\end{array}$ \\
\hline 2005 & 71765 & 613.088395 & 1879.597115 & 1110.132785 & 793.792665 & 656.865045 \\
\hline 100 -year return period & 72109 & 616.027187 & 1888.606819 & 1115.454121 & 797.597649 & 660.013677 \\
\hline 50-year return period & 70905 & 605.741415 & 1857.072855 & 1096.829445 & 784.280205 & 648.993465 \\
\hline 10 -year return period & 61697 & 527.077471 & 1615.906127 & 954.390893 & 682.430517 & 564.712641 \\
\hline 5-year return period & 59804 & 510.905572 & 1566.326564 & 925.108076 & 661.492044 & 547.386012 \\
\hline
\end{tabular}

\section{The Human Development Report Mumbai (2009)}

Based on the census data of 2001, the Human Development Report Mumbai (2009) found the Human Development Measure for wards in the Mumbai City. The HDM index uses the same three dimensions and methodology identified by UNDP for the calculation of HDI Index. However the indicators chosen to represent each of the dimension does not correspond to the international reports of UNDP. The indicators chosen for the HDM index were Education, Health and income. Table 9 shows the census data for the year 2001 and 2011 to analyze the socio-economic condition of the residents in the $\mathrm{H} / \mathrm{E}$ ward of Mumbai.

Table 9. Census Data used to calculate the HDM INDEX FOR $\mathrm{H} / \mathrm{E}$ Ward of Mumbai

\begin{tabular}{|c|c|c|}
\hline & 2001 & 2011 \\
\hline Total Population & $5,80,835$ & $\begin{array}{l}\text { 5,57,239 (Population } \\
\text { Range 5-6 lakhs) }\end{array}$ \\
\hline Slum Population & $\begin{array}{l}457622 \quad(78 \% \\
\text { of total } \\
\text { population) }\end{array}$ & $42.1 \%$ \\
\hline $\begin{array}{l}\text { Percentage of } \\
\text { Marginal } \\
\text { workers to total } \\
\text { Population }\end{array}$ & $\begin{array}{l}2.1 \% \quad \text { (District } \\
\text { Average } \\
2.02 \%)\end{array}$ & $\begin{array}{l}\text { Main Workers }=38.6 \% \text {, } \\
\text { Marginal Worker }=3.2 \% \text {, } \\
\text { Total Workers }=41.4 \%, \\
\text { Non workers }=58.6 \% \\
\text { District Average } \\
\text { Main W }=37.6 \%, \\
\text { Marginal workers }=2.3 \% \text {, } \\
\text { Total Workers }=39.9 \% \\
\text { and Non Workers }=60.1 \% \text { ) }\end{array}$ \\
\hline $\begin{array}{l}\text { Infant Mortality } \\
\text { Rate }\end{array}$ & $\begin{array}{l}33.29 \text { (District } \\
\text { average- } \\
34.57 \% \text { ) }\end{array}$ & \\
\hline $\begin{array}{ll}\text { Literacy } & \text { rate } \\
\text { (percent) } & \end{array}$ & $\begin{array}{l}75 \quad \text { (District } \\
\text { average is } 77 \text { ) }\end{array}$ & $\begin{array}{l}\text { 89.2, (District average is } \\
89.9 \text { ) }\end{array}$ \\
\hline $\begin{array}{l}\text { Average } \text { Age at } \\
\text { Death 2004- } \\
2006\end{array}$ & $\begin{array}{l}50.19, \text { District } \\
\text { Average- } 52.19\end{array}$ & \\
\hline
\end{tabular}

The H/E ward is among the worst affected areas in the 2005 Floods. The socio-economic and geographical condition of the $\mathrm{H} / \mathrm{E}$ ward makes it very susceptible to the flood risk. The above analysis of census data shows that the coping capacity of the people is also feeble. The HDI index based on the census data of 2001 for the H/E ward was one of the lowest among the 24 wards. Figure 16 shows the HDI index for the 24 wards of Mumbai.

The slum population residing in the H/E ward was $78 \%$ of the Total Population, highlighting the increased Risk in the $\mathrm{H} / \mathrm{E}$ Ward. Also, the total marginal worker population is higher than the district average, which shows that many people face Job Risk and are employed in the informal sectors. The census data of 2011 shows a similar pattern: the Population of marginal workers is higher than the district average. Although the total working Population of the ward has increased, one reason for this could be the marginal worker population. Also, the Slum population forms $42.1 \%$, which still forms the majority of Population at Risk.

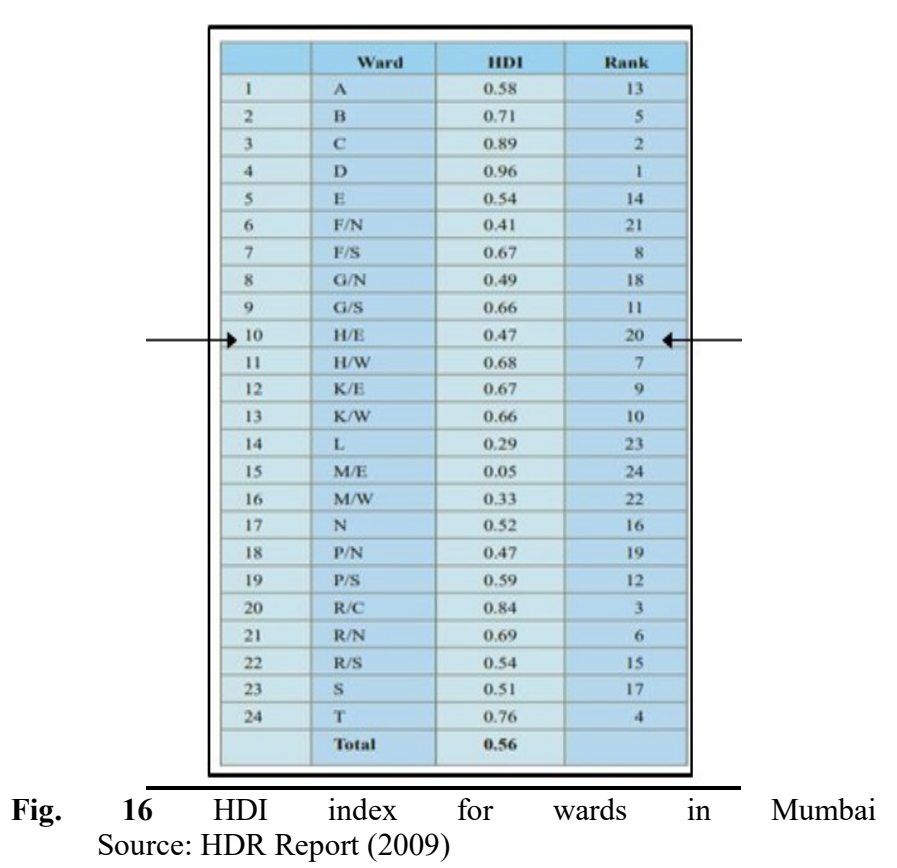




\section{Socio-Economic Assessment of the affected Population in the H/E Ward}

The chapter on "Socio-Economic Assessment of 2005 Floods, Resettlement and Rehabilitation, and Post Disaster Measures" in the Integrated Impact Assessment of Mithi River (2014) gave a detailed description about the population characteristics of the affected area. Two locations in H/E ward i.e., Valmiki Nagar and Mahatma Gandhi Nagar, were selected. Figure 17 shows the Slum and other vulnerable areas in the H/E ward who got affected during Mumbai Floods 2005. The above mentioned Report mentions that one of the most affected Populations in the 2005 floods was living near the Mithi River Catchment area and Vakola Nala, which both comes under the H/E ward boundary. The report also mentions that the relocation program has been started by MMRDA to relocate the Population residing near the river creek. Even then, a significant number of populations stay in the vulnerable areas and face the Risk of recurrent floods in Mumbai. Hence it becomes crucial to understand the Risk and problems faced by them.

\section{Socio-Economic Profile}

Valmiki Nagar lies at the junction of Vakola Nala and Mithi River. The Report mentions that there are 200 to 250 Households. Most people are Valmikis from Haryana and mostly engaged in menial jobs such as sweeping, cleaning, and Sanitation Jobs. The location of the Valmiki Nagar makes it more susceptible to the Risk of flooding. The 40-50 houses were located in a row beside the Nala. There is a small space for the Pedestrian to walk between the Nala and the houses. The homes also face the Vakola Nala, which increases the Risk during the floods.

Ashok Nagar lies at the banks of the Vakola Nala. The Report mentions there are 280 households. The majority of the Population is migrants from the other part of the state and lives in a destitution state. Households are burdened with lots of borrowings. Most of the male members of the family are auto drivers. The location of the houses makes them more susceptible to flood Risk. As these areas' location is near the Vakola Nala, proper disposal of Waste becomes more critical. The wastewater is directly fed into the River, which clogs the water flow and increases localized flooding. Despite the trauma and financial losses incurred by the people in these vulnerable locations during the 2005 floods, there are several reasons for which people don't want to relocate from the current area.

a- The places offered were far away. Also, the areas provided by the government were not satisfactory.

b- Also, many people mentioned that they were not offered rehabilitation even when they were affected by the floods.

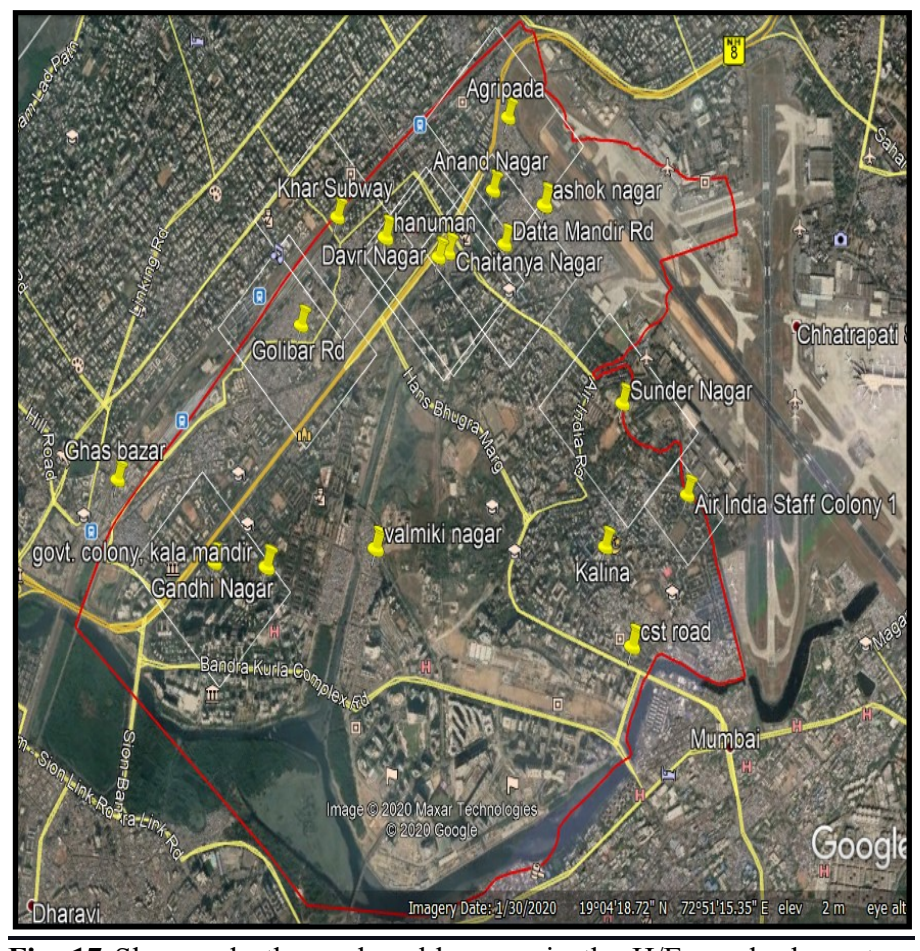

Fig. 17 Slum and other vulnerable areas in the H/E ward who got affected during Mumbai Floods 2005.

Source: Google Earth Pro

Some of the eligible family's couldn't relocate because of a lack of documents. Also, the preparedness of the people to cope with the flood risk remains inadequate. Few steps taken by the local people include (i) shifting the Valuables to the higher elevation. (ii) Moving the valuables to a safer place (iii) People who didn't have the option of shifting the valuables, mostly packed their things in the plastic. Although these steps are significant but there is a urgent need of institutional support to combat the severe impacts of Urban Flooding.

\section{CONCLUSION}

The aim of the research was to assess the current \& Future Flood Risk in the H/E Ward of Mumbai. The findings on "Flood Risk Assessment in the H/E Ward of Mumbai" which analysis the current \& future flood risk in Mumbai shows an increase in the inundation extent for the 100 year return period, which highlights that there would be an increase in the total affected Population and losses incurred by them. This study also highlights some of the reasons for the increased flood impact in the H/E Ward- Significant changes in the LULC; a substantial population is staying near the banks of the Mithi River \& Vakola Nala, disposal of wastewater in the Mithi River by the industries. The Section on the effect on the Marginalized Population in the $\mathrm{H} / \mathrm{E}$ Ward shows that the people's adaptive capacity is deficient. Most of the affected Population are poor people, employed in menial jobs, chosen to stay in the riskier site because of proximity to work. As the literature suggests, Adaptation Planning starts with an 
effective Risk Assessment. Hence the Risk Assessment highlights the increased risk faced by the $\mathrm{H} / \mathrm{E}$ Ward and shows that it requires an urgent attention for the effective Flood Risk Reduction \& Adaptive Planning. Also, the Flood Plain Maps maps can be used to prepare the flood preparedness and mitigation/ management strategy as well as to take precautionary measures for avoiding flooding risk in the identified flood-prone area.

Acknowledgment I would like to thank Mr Vishal Dubey for his technical contribution in HEC-HMS and HEC-RAS simulation and his constant support in the work.

\section{References}

Baker, J. L. (Ed.). (2012). Climate change, disaster risk, and the urban poor: cities building resilience for a changing world. The World Bank.

Bernstein, L. (Ed.). (2007). Climate change 2007: Synthesis report, summary for policymakers. Intergovernmental Panel on Climate Change (IPCC).

Brocal, F., González-Gaya, G., Sebastián, M. A., Reniers, G. L. L. M. E., \& Paltrinieri, N. (2019). Emerging Risk Management Versus Traditional Risk: Differences and Challenges in the Context of Occupational Health and Safety. In Proceedings of the 29th European Safety and Reliability Conference. Research Publishing.

Devia, G. K., Ganasri, B. P., \& Dwarakish, G. S. (2015). A review on hydrological models. Aquatic Procedia, 4, 1001-1007.

Dhiman, R., VishnuRadhan, R., Eldho, T. I., \& Inamdar, A. (2019). Flood risk and adaptation in Indian coastal cities: Recent scenarios. Applied Water Science, 9(1), 5.

Field, C. B., Barros, V., Stocker, T. F., \& Dahe, Q. (Eds.). (2012). Managing the risks of extreme events and disasters to advance climate change adaptation: special report of the intergovernmental panel on climate change. Cambridge University Press.

GoI (2011), Census 2011 Tables on Mumbai.

Government of India. (2011). District Census HandbookMaharashtra.
Hallegatte, S., Ranger, N., Bhattacharya, S., Bachu, M., Priya, S., Dhore, K., \& Patwardhan, A. (2010). Flood risks, climate change impacts and adaptation benefits in Mumbai.

http://www.censusindia.gov.in/Tables Published/Basic Data Sheet. $\underline{\operatorname{aspx}}$

Human Development Report (HDR). (2009). Mumbai human development report, 2009.

Jha, A., Lamond, J., Bloch, R., Bhattacharya, N., Lopez, A., Papachristodoulou, N., ... \& Barker, R. (2011). Five feet high and rising: cities and flooding in the 21st century. The World Bank.

Kothyari, U. C., \& Garde, R. J. (1992). Rainfall intensity-durationfrequency formula for India. Journal of Hydraulic Engineering, 118(2), 323-336.

MCGM (2006). Fact Finding Committee on Mumbai Floods, Final Report. Volume I, March 2006. Municipal Corporation of Greater Mumbai

NDMA. (2008). National disaster management guidelines: Management of floods.

Nicholls, R. J., Hanson, S., Herweijer, C., Patmore, N., Hallegatte, S., Corfee-Morlot, J. \& Muir-Wood, R. (2008). Ranking port cities with high exposure and vulnerability to climate extremes.

Parthasarathy, D. (2009). Social and environmental insecurities in Mumbai: towards a sociological perspective on vulnerability. South African Review of Sociology, 40(1), 109-126.

Parthasarathy, D., Pandey, N., Davis, J., \& Ambe, Sonam. (2014). Socio-economic Assessment of 2005 Floods, Resettlement and Rehabilitation, and Post-disaster Measures. Integrated impact assessment of Mithi River: Remote Sensing, GIS and SocioEconomic Studies of Mithi catchment.

Patankar, A. (2015). The exposure, vulnerability, and ability to respond of poor households to recurrent floods in Mumbai. The World Bank.

Wright, D. B. (2015). Methods in Flood Hazard and Risk Assessment (No. 22982). The World Bank.

Zope, P. E., Eldho, T. I., \& Jothiprakash, V. (2012). Study of spatiotemporal varaitions of rainfall pattern in Mumbai City, India. Journal of Environmental Research and Development, 6(3), 545-553.

Zope, P. E., Eldho, T. I., \& Jothiprakash, V. (2015). Impacts of urbanization on flooding of a coastal urban catchment: a case study of Mumbai City, India. Natural Hazards, 75(1), 887-908. 